\title{
W. G. Sebald's Revisions of Roland Barthes
}

\section{Abstract}

W. G. Sebald's work has frequently been compared to that of Roland Barthes; James Wood is typical in speculating that Austerlitz is 'in deep dialogue' with Camera Lucida. Evidence from Sebald's archive both supports and complicates such claims. Sebald first read Barthes in the early 1990s, engaging with him in his art criticism, yet Sebald's compositional practice in The Emigrants, which involved erasing an image's indexical relationship to its referent, shows a rejection of the central ontological claim of Camera Lucida. Sebald returned to Barthes in the late 1990s while composing Austerlitz, and revised the draft manuscript so that the published version directly references Sebald's reading of Camera Lucida. Through an extended engagement with Barthes, Sebald contested the indexical nature of photography in order to reflect upon the desires that led to the figuration of trauma and history as an indexical trace at the end of the twentieth century.

\section{Keywords}

Sebald, Barthes, revision, photography, indexicality

W. G. Sebald's The Emigrants (1992) is made up of four long narratives, each featuring an unnamed narrator telling the story of a German émigré, who in doing so reveals the story of his own life. Like all Sebald's 'semi-documentary prose fictions', The Emigrants consists of prose interspersed with reproductions of images, mostly but not exclusively reproductions of photographs. ${ }^{1}$ At the end of the second narrative, 'Paul Bereyter', the narrator recalls the map of his village's railway network that Bereyter, a school teacher, drew on a blackboard and which the students had to copy into their notebooks. Right at the point where the text in the German Eichborn edition describes the map that Bereyter 'gemalt hatte' ('had drawn'), a reproduction is presented of a child's drawing of a map on which is written: 'So ist es seit dem 4.10.1949' ('This is how it has been since the 4.10.1949'). ${ }^{2}$ As with many of Sebald's images, what at first seems like an illustration confirming the authenticity of the prose narrative soon refracts into construction of puzzling complexity.

The image is a reproduction of a map, an iconic form of visual signification. Yet the text, 'So ist es seit dem 4.10.1949', expresses a different understanding of the visual sign: the photographic image as index. Independent of what it shows, the image shows of something that 'this is how it has been', that a notebook has been like this since a particular moment in time. Both modes of visual signification are explained in the image by text, but text functions differently in relation to each mode. Names identifying buildings help a viewer to interpret the map, but they do not determine the image's iconicity, whereas the statement 'So ist es seit dem 4.10.1949' is a theoretical explanation of the ontology of an image incorporated into a reproduction of that image itself. The image neither resolves into a singular mode of signification nor dissolves into an equally simplistic aporia. Since the prose invites the reader to scrutinize the image 'mit 
möglichster Genauigkeit' ('as carefully as possible'), the questions raised by this image must be related to the narrative in which it appears $(91 ; 61)$. Why do these questions unfurl out of an image of a map of the railway tracks on which the fictional Paul Bereyter committed suicide at the end of a life ruined by the Nazi persecution of the Jews?

In attempting to answer the questions raised by such images, or at least to figure out what questions they are asking, critics have turned to a variety of theoretical approaches, from Benjamin's writings on Surrealism to Foucault's account of modernity. ${ }^{3}$ Yet by far the most common approach to interpreting images in Sebald's work has be to draw on the long-established theorization of the photographic image as an index, and to argue that the purpose and value of such images lies in their investigations of memory, trauma, or bearing witness. ${ }^{4}$ As J. J. Long pointed out as early as 2007, the most frequently invoked theorist of photography in Sebald criticism has been Roland Barthes. ${ }^{5}$ This is unsurprising given that Camera Lucida (1980) offers one of the most well-known theorizations of the photograph as index and one of the most influential reflections on the relationship of photography to the explorations of memory, autobiography, and history that are so clearly present in Sebald's work.

More recent criticism has only intensified the association between Barthes and Sebald. Avi Kempinksi argues Austerlitz. (2001) stages a failed quest for the mother image, reversing the plot of Camera Lucida. According to Margaret Olin, 'Sebald's protagonists' are '[1]ike Roland Barthes' because 'they want images to restore the past, to retrieve lost connections'. Marianne Hirsch argues Austerlitz extends Barthes's account of the photographic referent as 'the revenant, the ghost that returns to look at the image', and like Olin, her claims are based on the assumption that Sebald's work shares Barthes's understanding of the indexical nature of the photographic image. ${ }^{6}$ Public sphere critics have added to these comparisons. In his introduction to the tenth anniversary Englishlanguage edition of Austerlitz, James Wood writes that Austerlitz is in 'deep dialogue' with Camera Lucida. Brian Dillon wrote in the same year that 'W. G. Sebald admitted a profound debt to Camera Lucida; in Austerlitr, the protagonist's search for an image of his lost mother is clearly modeled on Barthes's desire for a glimpse of the unique being. ${ }^{7}$

If these latter claims risk speculating through assertion, they do follow Sebald's open declaration of a debt to 'La chambre clair, the wonderful text by Barthes'. 'When asked about the role photographs played in his work, Sebald responded: 'I've always liked image-text relationships. In the 70 s there were very interesting things written about photography by Susan Sontag, Roland Barthes, John Berger. I felt a direct rapport with things said in these essays. .' While Sontag is mentioned in the critical essay 'Like Day and Night: On the Pictures of Jan Peter Tripp' (1993), Sebald primarily engages with Barthes. In an essay which aims to define the relationship between photography and Tripp's painting, and to define art's difference from photography, Barthes is taken to be the authoritative theorist of the photographic image. Mary Jacobus argues that in this revealing essay 'Sebald could be writing of his own work, with its melancholy accumulation of detail and its memorial testimony to crystallized things' ${ }^{10}$ Sebald is also writing of his own work's relationship to Barthes. After publishing The Emigrants, Sebald turned to Barthes's account of photography to implicitly define the understandings of photography to which his own work was responding.

Sebald's relationship to Barthes is neither one of simple identity nor simple opposition. It changed and was revised over time, and these changes can be traced in multiple acts: Sebald's annotations in his copy of Camera Lucida, explicit commentary in criticism, 
translations of his texts, and the themes of his work. Sebald's engagement with Barthes can also be traced in his compositional practice - a term intended to encompass the composition of images as well of texts - and reconstructing how Sebald composed his images reveals an understanding of photography that developed through an engagement with Camera Lucida yet cannot be reduced to an extension of it. Attention to the manuscripts and material preserved in Sebald's archive is necessary to track the ways Sebald revised his relationship to Barthes over the course of the 1990s and contributes to a better understanding of Sebald's visual techniques, complementing the studies of his prose style offered by Ben Hutchinson, Lynn L. Wolff and Carol Jacobs. ${ }^{11}$

Tracking the engagement of a writer for whom photographs were central to his work with one of the most influential theorists of photography shows both the reasons for the lasting influence of Camera Lucida and what investments in photography need to be overturned in order to move beyond it. Geoffrey Batchen has written with more than a little frustration of how Camera Lucida remains 'the most quoted book in the photographic canon', responsible for an excessive focus on indexicality as the key to all photographic mythologies. ${ }^{12}$ Theorizing photography beyond indexicality has become a pressing task in photography theory, and Sebald's revisions of Barthes offer a case study of one attempt to move beyond the index. ${ }^{13}$

Conceptualizing a photograph as an index was the basis for its equation with the psychic structure of trauma as far back as Freud. ${ }^{14}$ Uncovering the ways in which Sebald's compositional practice does not treat the image as index also shows his work's contestation of the pervasive association between photography and trauma that developed towards the end of the twentieth century. Trauma theory emerged from shifts in psychiatric diagnoses, debates in Holocaust historiography, as well as the interventions of theorists such as Cathy Caruth. ${ }^{15}$ It led to an exponentially expanding use of a psychoanalytic theory of individual subject formation to analogically explain categorically different phenomena such as historical explanation or ethical responsibility. Trauma also came to be aestheticized into what Amy Hungerford has described as a 'formal handbook' and consciously used as a model for works of art as and literature. ${ }^{16}$ There emerged, according to Roger Luckhurst 'a trauma paradigm that has come to pervade the understanding of subjectivity and experience in the advanced industrial world'. ${ }^{17}$

There also emerged a critique of this trauma paradigm. To 'equate history with trauma', Dominick LaCapra has argued, 'is to obscure dimensions of history that may help to avert the incidence of trauma or to mitigate or at least counteract its effects'. When trauma becomes a handbook for art, works aim at a "tragic" identification or rather uncontrolled transferential relation' in which the viewer is presumed to repeat the trauma, thus identifying aesthetic experience with the suffering of the original victim. ${ }^{18}$ This critique has recently gained traction in literary studies. Readings of Toni Morrison by Heather Love and Stephen Best have praised Morrison's writing for refusing the figuration of the African-American past as a form of historical trauma that haunts black experience today. ${ }^{19}$ They exemplify the need to historicize the trauma paradigm that developed at the end of the twentieth century to make clear the difference between traumatic memory in itself and the techniques used to represent it. Sebald's engagement with Barthes was a means by which he came to articulate this difference, offering in Austerlitz the portrayal of what is lost when autobiography and history are reduced to the photographic return of the indexical traces of the past. 


\section{Vertigo in Jerusalem: Barthes in The Emigrants}

The books preserved in Sebald's library confirm his statement that Berger, Sontag, and Barthes were the writers on photography with whom he felt a 'direct rapport'. Sebald owned and annotated a 1982 Penguin edition of Sontag's On Photography (1979), a 1980 Writers and Readers' Co-operative edition of Berger's About Looking (1980) and a 1984 Fontana edition of Barthes's Camera Lucida (1980). As Clive Scott has written, Camera Lucida is the most heavily annotated of these books, with different kinds of pen suggesting its was read and annotated a number of times. ${ }^{20}$ Sebald underlined or sidelined about 40 passages, marks at times accompanied by annotations where reading slipped into composition. The reproduction of Lewis Hine's Idiot Children in an Institution (1924) is accompanied by what reads like a brief poem in English: 'and how the little boy / seems to stand in a / kind of shallow hole / + the girl almost / appears / to / levitate'.

Traces of reading must be treated with critical tact. At most they can be partial evidence for arguments that remain open to revision or augmentation. Marking a passage does not always signal agreement: it can mean disagreement, or neither, or both. If the turn in genetic criticism towards investigating authors' libraries has helped remind us that historically developing practices of reading are also practices of writing, or what Stephen Orgel calls 'reading in action', claims that all such traces necessarily become part of an avant-texte assume what it should be the critic's task prove. ${ }^{22}$ They also rely on a mode of retrospective activation which produces the kind of teleological understanding of a work's creation that genetic criticism at its best cautions against. Do the notes I make in my copy of Austerlitz become avant-textes only if I get around to finishing this article? Or if it gets published? If they come into being retrospectively, how can the meaning of the original reading be differentiated from the later significance obtained by becoming part of a work? When does reading take place?

If we maintain the difference between an annotation as an act of interpretative reading and an annotation as an avant-texte, we are able to track the changes that can take place between the events of reading and composition. Sebald's first allusion to Barthes in his essay on Tripp occurs during his attempt to counter the dismissal of Tripp's photorealism as merely a kind of trompe l'oeil, Sebald instead defining his style as capable of 'conjuring up the so-called effet du réel as it were from nothing. ${ }^{23}$ In a 1996 interview, he described his own practice of embellishing historical sources with minor details as an attempt 'to provide l'effet $d u$ réel. ${ }^{24} \mathrm{~A}$ few years later, when collaborating with Michael Hulse to translate Schwindel. Gefüble (1990) into English, Sebald significantly revised his description of Pisanello's realism to include this allusion to Barthes. If the German text located Pisanello's 'realism' in 'die Art, wie es ihm gelingt, diese Kunst in einer mit der realistischen Malweise eigentlich unvereinbaren Fläche aufgehen zu lassen', the English edition, translated almost ten years later, states that Pisanello's realism 'succeeded in creating the effect of the real, without suggesting the depth dimension, upon an essentially flat surface. ${ }^{25}$ Sebald's engagement with Barthes caused him to revise his description of his own techniques and the language of his prose. How else did Barthes feature in Sebald's work in the early 1990s, and how else did this change over the course of the decade?

In arguing that Tripp's painting is not a form of photorealism, a style which shares the 'tendency to reification implicit in its naturalist mode of depiction', Sebald offers a different explanation of how Tripp's paintings, as works of art, engage with photography (163). Taking up Sontag and Barthes's claim that photography produces a 'tautology' of 
reality, Sebald argues that art, in contrast, involves 'the transcending of that which, according to an ineluctable law, has necessarily to be the case' (163). Expanding on the difference between photography and art, Sebald writes:

Roland Barthes saw in the - now omnipresent - man with a camera an agent of death, and in photographs something like relics of life continually giving way to death. Where art differs from such a morbid affair is the fact that the proximity of life to death is its subject, not its obsession. Art deploys the deconstruction of outward appearances as a means of countering the obliteration, in endless series of reproductions, of the visible world (164).

Sebald noted in his copy of Camera Lucida Barthes's explanation of why photography 'produces Death while trying to preserve life' (97): the death photography confirms, according to Barthes, is the viewer's: '[e]ach photograph always contains this imperious sign of my future death' (72). What Barthes learns from the Winter Garden photograph is that the subject of every photograph is 'my total, undialectical Death' (72).

Barthes provides the theory of photography against which Sebald defines the purpose of art in the age of the technical reproduction of reality. Art does not counter photography's production of death and obliteration of the visible world by turning away from the photographic image - what Sebald dismisses as the 'modernist' account of the relationship between photography and painting (299). Instead, art must engage ever more closely with photography and the appearances it produces: the value of Tripp's paintings lies in the subtlety with which the 'the photographic raw material which they take as their starting point is painstakingly modified' (301). This definition of art in terms of what it is not evinces what Ben Hutchinson calls the 'dialectical imagination' Sebald developed through his reading of the Frankfurt School. In his copy of Dialectic of Enlightenment, Sebald side-lined the following passage: 'The moment in the work of art by which it transcends reality cannot, indeed, be severed from style; that moment, however, does not consist in achieved harmony, in the questionable unity of form and content, inner and outer, individual and society, but in those traits in which discrepancy emerges, in the necessary failure of the passionate striving for identity'. ${ }^{26}$ For Sebald, art redeems a photographically mediated reality by virtue of the discrepancies it introduces to the appearances photography produces.

Sebald's essay on Tripp is one engagement with Barthes's account of photography. The composition of The Emigrants was another. Camera Lucida is an investigation into the essence of photography, and Barthes's turn from hermeneutics to ontology presents itself as a move from suspicion to the belief that the essence of photography is its indexical relationship to what it shows. No matter what appears in a photograph, it confirms '[t]hat-has-been' (77). As Jean-Michel Rabate has written, '[b]y stressing the ontological nature of the apparent mystery by which real past objects or people leave an "emanation" as a visual trace of their presence in the world, rather than the authorial or ideological manipulations by which an operator transforms or frames a material that is still plastic or malleable, Barthes deprives photography of its productive transitivity. ${ }^{27}$ The manipulations of the author and the malleability of the material are Sebald's precise concerns. Attending to how Sebald composed his images in The Emigrants uncovers a practice aimed at disrupting an image's indexical confirmation of reality and by so doing revealing our desires for such confirming traces of the real. 
The image with which this essay opened is a case in point. Its source was a notebook belonging to one of Sebald's childhood friends, Jürgen Kaeser, to whom Sebald had written asking for material from their school days, and the notebook is preserved in Sebald's file for The Emigrants. To compose the image that made it into the published book, Sebald first photocopied a page from Kaeser's notebook, then wrote over the script in black marker to make the text more legible. On a photocopied reproduction of this image, he coloured the buildings in black, and then made a fourth reduced photocopy which was affixed to the typescript Sebald sent to the printers. These alterations seem trivial, so much so that their triviality is their point. The image which takes as its theme two modes of theorizing the photographic image, the index and the icon, is produced by a practice which ensures that very image cannot be theorized in either of those terms. Even if one takes the photocopied image as bearing an indexical relationship to its source through heat transfer, all that such an image confirms 'hasbeen' is Sebald's own process of construction.

If the images in The Emigrants aim at anything, it is to show that a photograph does not necessarily show 'that-has-been'. In the fourth narrative, Max Ferber remembers a photograph shown to him by his Uncle Leo, ostensibly depicting a book burning that took place on May 10, 1933. But this photograph, Leo reveals, was a 'Fälschung' ('forgery'), since the burning took place in the evening: the photograph was of a different crowd, onto which a plume of smoke and dark sky had been copied and pasted (274; 183). The narrator reflects he found this story improbable until he tracked down the photograph in an archive, only believing the photograph had been doctored upon seeing it with his own eyes. Text and image inform each other to affirm the truth of their mutual deception: neither Ferber nor the narrator believed Leo until they had seen the picture with their own eyes, yet both would simply have believed their own eyes were they not told Leo's story. The passage ends with Ferber recounting: ' $[\mathrm{u}] \mathrm{nd}$ so wie dieses Dokument eine Fälschung war, sagte der Onkel, als stelle die von ihm gemachte Entdeckung den entscheidenden Indizienbeweis bei, so war alles eine Fälschung von Anfang an' ('And just as that document was a fake, said uncle, as if his discovery were the one vital proof, so too everything else has been a fake, right from the start') (274; 183). Sebald stated of this image: 'I thought very consciously that this is the place to make a declaration. It couldn't be more explicit. It acts as a paradigm for the whole enterprise. The process of making a photographic image, which purports to be the real thing and isn't anything like, has transformed our self-perception, our perception of each other, our notion of what is beautiful'. ${ }^{28}$ The book burning image is a paradigm not only for how reproductions of photographs - a crucial distinction for Sebald - do not necessarily show what have been: it was also a paradigm for his own compositional practice.

A far less trivial manipulation of source material was required to compose the images of Uncle Ambros's 'Agendabüchlein' ('agenda book') (186; 126). The agenda book is presented as the source for the conclusion of the story of Ambros's life, the text claiming to be a transcription of the diary, reproductions of which are presented as proof. An attentive viewer would be able to observe that the text almost entirely transcribes the pages of the diary reproduced as images. An attentive viewer familiar with Sebald's handwriting, such as Ulrich von Bülow, would be able to observe that the handwriting in the diary is Sebald's own, and that when the text at breaks into an ellipsis it omits a word written in the diary, 'Schwindelgefühle': Schwindel. Gefüble being the name of Sebald's first book $(193 ; 131) .{ }^{29}$ That this was a conscious allusion is confirmed by the first draft of this section in the manuscript, which reads: 'Einen furchtbaren Herzschlag lang glaub ich 
mich in der Schweiz oder wieder daheim, muß mich geschwind ${ }^{\wedge}$. Schgefühle. ${ }^{\wedge}$ Muß mich einhalten an Cosmo [sic] ${ }^{30}$

A viewer whose attentiveness extends to inspecting the diary preserved in Sebald's archive would be likely to suffer their own 'Schwindelgefühle', feeling both dizzy and swindled, when they find the relevant pages in the diary are empty, and that the dates of the diary as represented in The Emigrants - '23 Martedi' and '24 Mercoledi' - have been cut out and pasted over the original dates, '27 Martedi' and '28 Mercoledi'. The diary in Sebald's archive is not from 1913, but from 1927, and belonged to a person named Alberto Beck, a German living in Milan. In order to transform pages from a 1927 diary into those from a 1913 one, Sebald cut and pasted the numbers to produce the correct correspondences of dates and days. To produce the images used in The Emigrants, he then photocopied these blank doctored pages, wrote in black pen on these copies, and then copied them again to produce the pictures included in the proofs sent to the printers. Once again this image bears no indexical relationship to its doctored source material, only to Sebald's process of technological manipulation.

What are the consequences of reconstructing Sebald's dexterity with scissors, glue, and a photocopying machine? The distinctive ethical value of Sebald's work has been a dominant feature of his critical reception. As Carol Jacobs has stated: 'Sebald's work is celebrated for its moral stand, for its turn not only to the Shoah [...] but to other historical and natural scenes of violence, ${ }^{31}$ Given the gravity of the subject matter and the strength of such claims, it is important to be precise about the formal techniques both literary and visual - which are their basis. The ethicality of Sebald's work has often been located in how it bears witness to the past, as when Eric L. Santner writes that 'what is issue in the interplay of image and text in these writings is the task of bearing witness to what exceeds our hermeneutic grasp of historical experience, ${ }^{32}$ In order to do so, however, Sebald had to refuse to bear witness to the historical archive: the material record of Alberto Beck's life had to be destroyed in order for the ethical effect praised by Santner to be created. Even if one accepts that certain aspects of historical experience are beyond our understanding, whether through trauma or hermeneutic uncertainty, then Sebald's use of the historical archive in his compositional practice is more complex than simply bearing witness. What guides Sebald's interlacing of text, image, and ethics is an assumption he underlined in his copy of Camera Lucida: that language is by nature fictional' whereas the photograph 'is authentication itself. (87) Just like the authenticity effect produced by a photograph, an ethics of bearing witness becomes an aesthetic effect, not an impossible task. If Sebald's art is ethical, it is ethical when it lies.

Photography's ability to produce illusions of authenticity, not its analogical status as an index for the traumatic unknowability of the past, made it a model for Sebald's poetics:

[Photographs] act as a token of authenticity - but they can be deduced, forged or purloined. And of course that in turn throws up one of the central problems of fiction writing, which is that of legitimacy and the arrival at the truth on a crooked route. This is why 'vertigo' in German has a double meaning Schwindel in German means 'swindle'. What right do you have to write about any of these things? Have you been there, and felt these things for yourself? ${ }^{33}$

The double meaning of 'ein Schwindel' - an affective state of uncertainty, and an act of conscious deception - is how Sebald connects his practice of forging photographs to the ethical legitimacy of his work. Attempting to understand the past can trigger a feeling of 
vertigo, yet the question Sebald's compositional practice asks is whether an aesthetic swindle is the cause or the cure for this feeling, a question inscribed, through a photocopier's illusion, into the swindle that is Ambros's diary.

The composition of Ambros's diary also shows the relationship of this concept to Camera Lucida. Sebald noted that Barthes suffered his own feeling of vertigo, trigged by his discovery of the 'that-has-been' asserted by every photograph, underlining his response to a photograph of the road to Jerusalem by August Salzman: 'At the limit there is no need to represent a body in order for me to experience this vertigo of time defeated' (97). Ambros's story also ends with a feeling of vertigo in Jerusalem. Glancing out of his window, Ambros's diary records that memory 'macht einen schweren, schwindligen Kopf, als blickte man nicht zurück durch die Fluchten der Zeit, sondern aus großer Höhe auf die Erde hinab von einem jener Türme, die sich im Himmel verlieren' ('makes one's head heavy and giddy, as if one were not looking back down from the receding perspectives of time, but rather down on the earth from a great height, from one of those towers whose tops are lost to view in the clouds') $(215 ; 145)$. For Barthes, a photograph triggers vertigo because it is 'an instance of reality' in contrast to 'the elaborations of the text, whether fictional or poetic, which itself is never credible down to the root (97). Sebald's 'Schwindel', in contrast, is caused by art's ability float free, like Ambros, from the determinations of time and history, to levitate like the boy photographed by Lewis Hine. Just as Sebald agreed with Barthes that photography produces death in order to offer a counter-definition of art, so too Sebald incorporated Barthes's feeling of vertigo into The Emigrants into one of many compositions which programmatically does not show 'that-has-been'. Or at least this was Sebald's reading of Barthes in 1993.

\section{Revising Austerlitz, Revising Barthes}

In a 1997 interview Sebald was asked about the relationship between image and narrative in his work:

In La chambre claire, the wonderful text by Barthes, there's a photograph of a little boy who had stepped out from behind his school desk into the walkway. He is wearing this little apron worn by French schoolboys. I can't remember exactly how Barthes comments on this image, but he asks the question about what might later have happened to this boy named Ernest. One can imagine that it's perhaps the year 1903 or so; and that fourteen years later this now about twenty year old man sacrificed his life on the Somme or in Passchendaele, or at another horrible place. One can image the life-trajectories that emanate from these photographs in a much, much clearer way that from out of a painting. ${ }^{34}$

If Sebald couldn't then remember exactly what Barthes said, it did strike his attention when he read Camera Lucida, side-lining Barthes's question: 'it is possible that Ernest, a schoolboy photographed in 1931 by Kertész, is still alive today (but where? how? What a novel!)' (84). In the same interview Sebald mentioned he had been hoarding a photograph showing 'two people standing on a stage' that he 'would like to do something with' (109). This photograph ended up appearing Austerlit, a decision in which Barthes also played a role.

In the same year Sebald recalled Barthes's proposal to write a novel emanating out of a photograph of a young boy, he had already begun work on Austerlitz, a book which 
Andreas Huyssen observes that in spite of Sebald's protestations to the contrary is his 'first "real" novel'. ${ }^{35}$ The composition of that novel was influenced by another engagement with Barthes: after completing a first draft, Sebald revised the text to produce a second draft that more closely followed Camera Lucida's plot of a quest for a mother-image, and inserted a cryptic yet specific reference to the notes he took on Barthes's text. In the same way that attention to Sebald's composition of images in The Emigrants reveals an engagement with Camera Lucida, so too does attention to the composition of the narrative of Austerlitr. But this return to Barthes at the end of the 1990 s saw Sebald revise the focus of that engagement away from indexicality as a semiotic or ontological question towards reflecting upon the implications of a desire for photographic indexicality to stand as an analogue for memory and historical knowledge.

The earliest evidence of Austerlitz's composition are notes on the reverse of a letter dated 17 January 1996, and on the reverse of a list of questions for a course on Weimar Cinema, about the life of Susi Bechhöfer, a woman who left Germany as a child on the Kindertransport. ${ }^{36}$ They confirm Sebald's later statement that viewing a documentary on Bechhöfer's life 'spurred' the writing of Austerlitr, the notes ending with the enigmatic statement: 'Austerlitz is now a person in his own right'. ${ }^{37}$ The manuscript of Austerlitz. consists of approximately 500 loose sheets, and is a fairly clean version which was the basis for a subsequent typescript. There are few deleted sections or major revisions aside from a few exceptions whose significance will soon become clear. As Lynn L. Wolff has written, it is likely these 'hand written manuscripts represent an already advanced stage of conceptualization and formulation', for they lack the extensive and often illegible sketches that are preserved in the files for The Emigrants and The Rings of Saturn. $^{38}$

The sheets are numbered in two paginations, one in pencil and one in black marker, each recording an act of taking stock after two phases of composition. The first 87 pages are numbered only in black marker. From pages 88 to 460 , each page is numbered twice, so that 88 is accompanied by a crossed out 63,89 with a crossed out 64 , and so on. This indicates that Sebald wrote a first draft which was numbered in pencil, and then rewrote the introduction, expanding 63 pages to 88 pages, which required renumbering the rest of the draft manuscript. The second pagination formed the basis for a summary of the narrative, mapping the events in the discours against the chronological histoire of Austerlitz's life, and noting what further revisions still needed to be made. For example, summarizing the middle section of the novel where Austerlitz discovers his adoption, remembers taking photographs as a boy, up to the reflections on country houses, Sebald dates these recollection to 'early 1997', and summarizes: 'Verabschiedung. Writing of notes / fotographs [sic]. (1st \& 2 nd meeting in Greenwich to be-filled in (2 or 3 pages) from p.275. Das Ende von Andr. Lodge. Landhäuser'.

The draft summarised by this plan ends at a sheet numbered 461, the text ending with the description of Austerlitz viewing the film from Theresienstadt which he imagines shows his mother: '...und die Hundertstelsekunden, die sich davon drehen, so geschwind, daß man sie nicht entziffern und festhalten kann' ('... while the hundredths of a second flash by so fast that you cannot read or capture them'). ${ }^{39}$ In this first draft Austerlitz's search for an image of his mother remains unfilled by a film, as he only imagines that the woman could be his mother. The next pages of the manuscript are written on a different kind of paper with a different kind of pen, are not paginated, are not included in the summary plan, are written straight through with no signs of revision, and correspond exactly to the published version of the text, indicating the conclusion 
was written later and appended to the second draft. In this conclusion, as in the novel itself, Austerlitz's quest is fulfilled not by the image of the woman in the film, which Vera denies is his mother Agáta, but by a photograph which Vera confirms as being Agáta 'wie sie damals gewesen war' ('as she had been then') (357; 354).

A number of textual details show that once Sebald had written this conclusion, he then revised the preceding narrative so it would better accord with the climactic yet unsatisfactory discovery of a photograph of Austerlitz's mother. For example, in the draft conclusion, Austerlitz's mother is called Agáta and her friend Vera - as in the published text. Yet in the first draft of the preceding narrative, the mother is alternatively called Amalia, Alma, or Sophia, and her friend Stela. ${ }^{40}$ The revisions show that once Sebald wrote the conclusion he went back and changed all the names so that they now became Agáta and Vera. Additionally, in one of the few major revisions preserved in the manuscript, Sebald also crossed out and rewrote the scene where Vera discovers the photographs hidden in a book by Balzac. Why did this scene require complete rewriting rather than the changing of the names?

The deleted and revised section runs in the published text from 'Als Vera mit ihrer Erzählung zu Ende war' to 'vor deiner Abreise aus Prag' ('When Vera had come to the end of her story' to 'before you left Prague' (259-263; 255-259). In the revised and published version, Vera discovers two photographs. The first shows two people standing on a stage, the photograph mentioned by Sebald in his 1997 interview, the second shows the Rose Queen's page who Vera claims in Austerlitz as a boy. However, in the first draft of this scene, Austerlitz receives three photographs. The scene begins with Stela giving Austerlitz a first photograph which almost shows Austerlitz's father Maximillian:

Die aus drei Teilen zu einer Art Halbrundansicht zusammengefügte zeigt, glaube ich, so sagte Stela, eine Betriebsversammlung in den Aero-Flugzeugwerken, die wenige Tage vor dem sogenannten Münchner Abkommen gehalten wurde \& auf welche Maximilian die sich immer bedrohlicher zuspitzende Lage in einer Weise kommentierte, die einige Zeitungen tags darauf als zu pessimistisch bezeichneten, während man doch in Wahrheit damals gar nicht genug sehen konnte. Maximilian selbst ist leider nicht auf der Fotographie, er saß gewiß mit auf dem

Rechnerpodium, das in der linken Ecke zu erkennen ist, aber außerhalb des von der Kamera erfaßten Rahmens, + wenn ich jetzt auf diesen linken Bildrand umschaue, kommt mir der Gedanke, er sei abgeschnitten zu Unrecht ^ denke ich, er sei abgeschnitten zu Unrecht ${ }^{\wedge} .^{41}$

The semi-circular shot assembled out of three joined parts shows, I think, said Stela, a workers meeting in the airplane factory, taken a few days before the socalled Munich Agreement, at which Maximilian commented upon the situation that was increasingly threatening to him in a way that some newspapers later described as too pessimistic, though in truth not enough could be seen at the time. Maximilian himself is unfortunately not in the photograph, he was certainly sitting on the podium you can see in the left-hand corner, but which is beyond the space captured by the camera, and when I look at the left hand side of the picture now, the thought strikes me he was cut off unfairly ${ }^{\wedge}$ I think he was unfairly cut off ${ }^{\wedge}$ [my translation].

This photograph which almost shows Austerlitz's father is preserved in Sebald's collection of photographs and postcards: folded into three sections horizontally, it is a 
panorama of a workers' assembly in Reichbenberg bearing the stamp of the Institut für Auslandsberiebungen in Stuttgart. After this, the rest of the deleted draft follows that of the published version.

In the first draft of this crucial scene - already the result of an advanced stage of conceptualization and integrated into a vision of the book as a whole - Austerlitz received three photographs: one almost showing his father, one which does not show his mother and father, and one ostensibly of himself. Sebald then wrote a conclusion in which after failing to find his mother in the Theresienstadt film, Austerlitz visits Prague a second time and finally discovers a photograph of his mother in the archives of the Prague National Theatre. Immediately after telling the narrator this story, Austerlitz gives this photograph of his mother to the narrator and announces his move to Paris to search for the traces of his father. It is not difficult to see the aesthetic logic behind Sebald's decision to revise the scene where Austerlitz first receives the photographs: once it was decided that the discovery of the mother's photograph would be the narrative's climax, and the decision to begin a search for his father a coda, removing the earlier photographic allusion to his father sharpened the plot line, emphasizing the overall shape of the narrative as a quest to discover an image of his mother which, in a concluding twist, does not bring Austerlitz's attempt to recover his past to an end.

This revision of the plot is what led so many readers to compare Austerlitz to Camera Lucida. In this act of revision, Sebald himself alluded to his reading of Barthes. In the first draft, Stela discovers the photographs in a copy of Balzac's Le Peau de Chagrin. Yet in the revised version, she discovers them in a copy of Le Colonel Chabert. This change was made because in the conclusion - which Sebald wrote first - Austerlitz compares his life in Paris, searching for the traces of his father, to Balzac's Colonel Chabert, who is presumed dead after a battle yet returns to Paris year later, with Austerlitz quoting the line: 'Je suis le Colonel Chabert, celui qui est mort à Eylau' (396; 394). This was in fact a note Sebald had written in his copy of Camera Lucida opposite the Kertész photograph of a boy about which Barthes wanted to write a novel. While it is impossible to know when this line was written, Sebald's copy of Le Peau de Chagrin contains a review from the TLS of recent scholarship on Balzac, dated May 21 1999, suggesting he re-read this text by Balzac in composing Austerlitz, only to choose instead to make the allusion to Le Colonel Chabert, and thus to his own reading of Barthes.

This was a reading which compared Barthes's belief that the subject of every photograph is the viewer's own death to what it would be like to live as Colonel Chabert: a ghostly figure, half-dead, melancholically searching for his lost past. The last words the narrator reports Austerlitz speaking are his invitation to study the photographs 'die als einziges übrigbleiben würden von seinem Leben' ('[which] one day, would be all that was left of his life' (410; 408). Through his identification with Chabert, Austerlitz's reduction to his photographs is equated with Barthes's discovery that our death is the subject of photography. But to recall Sebald's distinction between photography and art, '[w] here art differs from such a morbid affair is the fact that the proximity of life to death is its subject, not its obsession'. If the story of Austerlitz the character ends with his identification with the photographs that serve as means to unsatisfactorily recover the past, Austerlitz the novel ends with a different understanding of photography. In Heshel's Kingdom, the book given by Austerlitz to the narrator, Dan Jacobson begins his search for his grandfather's past with a single studio photograph, but what his search uncovers is 'die untergegangene Vorzeit seiner Familie und seines Volks, die sich, wie er weiß, von dort drunten nicht mehr heraufholen läßt' ('the vanished past of his family and his 
people which, as he knows, can never be brought up from those depths again') (416; 414). Jacobson's memoir is insistent that the past cannot return to the present: when visiting the site of a former synagogue, he writes as if in direct refutation of Sebald's earlier work that ' $t$ the abyss of the past does not have to be figured for us by bottomless pits, vertiginous plunges, stones dropping forever down soundless chambers'. The past is simply a 'darkness that gives back nothing'. ${ }^{42}$

Although Sebald revised the plot of Austerlitz's life to closely follow that of Camera Lucida, Austerlitz the novel does more than simply repeat Barthes's text. It is a revision of Sebald's earlier interest in formal, even playful, refutations of the indexicality of the photographic image, towards a reflection upon why we, like Barthes, desire photography's indexicality to be an essence with which we can explain the truth of ourselves and of our history. Austerlitz's desire for an image of his mother, like all desire, remains unfulfilled: after completing this quest, he repeats it with a search for his father, then for Marie, a chain which one suspects will continue for ever. Austerlitz, the novel shows the ways in which a desire for photographic indexicality can leave us like 'relics of life continually giving way to death'. Sebald's revisions of Barthes show that we have attached so much importance to the photographic index as a way of avoiding what is most difficult about the past: that is just that, past.

\footnotetext{
${ }^{1}$ W. G. Sebald, 'Stipendium Des National Endowment for Science, Technology and the Arts (NESTA)', Bestand A: Sebald, HS005243182, Deutsches Literaturarchiv Marbach. ${ }^{2}$ W. G. Sebald, Die Ausgewanderten (Frankfurt: Eichborn, 2001), 91; The Emigrants, trans. Michael Hulse (London: Harvill Press, 1996), 61. All further references, to the German and English editions, will be in the main body of the text.

${ }^{3}$ Judith Ryan, 'Fulgurations: Sebald and Surrealism', The Germanic Review 82:3 (2007), pp. 227-49; J. J. Long, W. G. Sebald: Image, Archive, Modernity (Edinburgh: Edinburgh University Press, 2007).

${ }^{4}$ Stephanie Harris, 'The Return of the Dead: Memory and Photography in W. G. Sebald's Die Ausgewanderten', German Quarterly 74 (2001): pp. 379-91; Carolin Duttlinger, 'Traumatic Photographs: Remembrance and the Technical Media in W. G. Sebald's Austerlitr, in J. J. Long and Anne Whitehead (eds.), W. G. Sebald: A Critical Companion, (Edinburgh: Edinburgh University Press, 2004), pp. 155-71; Samuel Pane, 'Trauma Obscura: Photographic Media in W. G. Sebald's Austerlitz', Mosaic, 38 (2005), pp. 37-54; George Kouvaros, 'Images That Remember Us: Photography and Memory in Austerlitr', Textual Practice 19:1 (2005), pp. 173-93; Maya Barzilai, 'On Exposure: Photography and Uncanny Memory in W. G. Sebald's Die Ausgewanderten and Austerlitz', in Scott Denham and Mark McCulloh (eds.), W. G. Sebald: History - Memory - Trauma, (Berlin: De Gruyter, 2006), pp. 205-18; Richard Crownshaw, The Afterlife of Holocaust Memory in Contemporary Literature and Culture (Basingstoke: Palgrave Macmillan, 2010).

${ }^{5}$ Long, W. G. Sebald: Image, Archive, Modernity, 67 n.4.

${ }^{6}$ Avi Kempinski,"'Quel Roman!": Sebald, Barthes, and the Pursuit of the Mother-Image', in Searching for Sebald: Photography After W. G. Sebald (Los Angeles: The Institute of Cultural Inquiry, 2007), pp. 456-71; Margaret Olin, Touching Photographs (Chicago; London: University of Chicago Press, 2012), 86; Marianne Hirsch, The Generation of
} 
Postmemory: Writing and Visual Culture After the Holocaust (New York: Columbia University Press, 2013), 50.

${ }^{7}$ W. G. Sebald, Austerlitr, trans. Anthea Bell (London: Penguin, 2011), xvii; Brian Dillon, 'Rereading: Camera Lucida by Roland Barthes', The Guardian, March 26, 2011, http://www.theguardian.com/books/2011/mar/26/roland-barthes-camera-lucidarereading.

${ }^{8}$ Christian Scholz and W. G. Sebald, "But the Written Word Is Not a True Document": A Conversation with W. G. Sebald on Literature and Photography', in Searching for Sebald, 105.

${ }^{9}$ Kenneth Baker and W. G. Sebald, 'Up Against Historical Amnesia', San Francisco Chronicle, October 7, 2001.

${ }^{10}$ Mary Jacobus, Romantic Things: A Tree, A Rock, A Cloud (Chicago; London: University of Chicago Press, 2012), 144.

${ }^{11}$ Ben Hutchinson, W. G. Sebald - Die Dialektische Imagination (Berlin: Walter De Gruyter, 2009); Lynn L. Wolff, W. G. Sebald's Hybrid Poetics: Literature as Historiography (Berlin: De Gruyter, 2014); Carol Jacobs, Sebald's Vision (New York: Columbia University Press, 2015).

${ }^{12}$ Geoffrey Batchen, 'Palinode: An Introduction to Photography Degree Zero', in Geoffrey Batchen (ed.), Photography Degree Zero: Reflections on Roland Barthes's Camera Lucida (Cambridge MA; London: MIT Press, 2009), 3; see also James Elkins, What Photography Is (New York: Routledge, 2011).

${ }^{13}$ See James Elkins, (ed.), Photography Theory (London: Routledge, 2007); Kaja Silverman, The Miracle of Analogy, or The History of Photography, Part 1 (Stanford: Stanford University Press, 2015).

${ }^{14}$ Sigmund Freud, Introductory Lectures On Psychoanalysis (Part III), trans. James Strachey, (London: Vintage, 2001), 295-6; Moses and Monotheism, An Outline of Psychoanalysis, and Other Works, trans. James Strachey (London: Vintage, 2001), 126.

${ }^{15}$ See Ruth Leys, Trauma: A Genealogy (Chicago and London: University of Chicago Press, 2000); Cathy Caruth, Unclaimed Experience: Trauma, Narrative, and History (Baltimore: Johns Hopkins University Press, 1996).

${ }^{16}$ Amy Hungerford, The Holocaust of Texts: Genocide, Literature and Personification (Chicago; London: University of Chicago Press, 2003), 100.

${ }^{17}$ Roger Luckhurst, The Trauma Question (London: Routledge, 2008), 2.

${ }^{18}$ Dominick LaCapra, Writing History, Writing Trauma, (Baltimore: Johns Hopkins University Press, 2014), xi; Dominick LaCapra, History and Memory after Auschwitz. (Ithaca: Cornell University Press, 1998), 101.

${ }^{19}$ Heather Love, 'Close but Not Deep: Literary Ethics and the Descriptive Turn', New Literary History 41:2 (2010), pp. 371-91; Stephen Best, 'On Failing to Make the Past Present', Modern Language Quarterly 73:3 (2012), pp. 453-74.

${ }^{20}$ Clive Scott, 'Sebald's Photographic Annotations', in Jo Catling and Richard Hibbitt (eds.), Saturn's Moons: W. G. Sebald - A Handbook, (London: MHRA and Maney Publishing, 2011), pp. 217-46.

${ }^{21}$ Roland Barthes, Camera Lucida, trans. Richard Howard (London: Fontana, 1984), 50. All further references will be in the main body of the text.

${ }^{22}$ Stephen Orgel, The Reader in the Book: A Study of Spaces and Traces (Oxford: Oxford University Press, 2015); Daniel Ferrer, 'Towards a Marginalist Economy of Textual Genesis', in Dirk van Hulle and Wim van Mierlo (eds.), Reading Notes (Amsterdam: Rodopi, 2004), pp. 7-18.

${ }^{23}$ W. G. Sebald, A Place in the Country, trans. Anthea Bell (London: Hamish Hamilton, 2013), 162. All further references will be in the main body of the text. 
${ }^{24}$ Carole Angier and W. G. Sebald, 'Who Is W. G. Sebald', in Lynne Sharon Schwartz (eds.), The Emergence of Memory: Conversations with W. G. Sebald, (New York: Seven Stories Press, 2007), 72.

${ }^{25}$ W. G. Sebald, Schwindel. Gefüble. (Frankfurt: Fischer, 1996), 88; Vertigo, trans. Michael Hulse (London: Harvill Press, 1999), 72-3.

${ }^{26}$ Theodor W. Adorno and Max Horkheimer, Dialectic of Enlightenment: Philosophical Fragments, trans. Edmund Jephcott (Stanford: Stanford University Press, 2002), 103; the original passage is in Dialektik der Aufklärung (Frankfurt: Suhrkamp, 1969), 139.

${ }^{27}$ Jean-Michel Rabaté, 'Introduction', in Jean-Michel Rabaté (ed.), Writing the Image After Roland Barthes, (Philadelphia: University of Pennsylvania Press, 1997), 8.

${ }^{28}$ Arthur Lubow, 'Crossing Boundaries', in The Emergence of Memory, 163.

${ }^{29}$ Ulrich von Bülow, 'The Disappearance of the Author in the Work', in Saturn's Moons, 249.

${ }^{30}$ W. G. Sebald, 'Die Ausgewanderten [Manuskript]', Bestand A: Sebald, HS005187486, Mappe 6, Deutsches Literaturarchiv Marbach.

${ }^{31}$ Jacobs, Sebald's Vision, xi-xii.

${ }^{32}$ Eric Santner, On Creaturely Life (Chicago: University of Chicago Press, 2009), xx.

${ }^{33} \mathrm{~W}$. G. Sebald, 'The Questionable Business of Writing', http:/ / www.amazon.co.uk/gp/ feature.html?ie=UTF8\&docId=21586.

${ }^{34}$ Scholz and Sebald, 'But the Written Word Is Not a True Document', 105.

${ }^{35}$ Andreas Huyssen, Present Pasts: Urban Palimpsests and the Politics of Memory (Stanford: Stanford University Press, 2003), 177.

${ }^{36}$ W. G. Sebald, 'Sebald, Winifred Georg an University of East Anglia <Norwich>', January 17, 1996, Bestand A: Sebald, HS005171092, Deutsches Literaturarchiv Marbach; 'Weimar Cinema: Essay Titles', 1996, Bestand A: Sebald, HS005171029, Deutsches Literaturarchiv Marbach.

${ }^{37}$ Maya Jaggi, 'Recovered Memories', The Guardian, September 22, 2001.

${ }^{38}$ Wolff, W. G. Sebald's Hybrid Poetics, 173.

${ }^{39}$ W. G. Sebald, Austerlitz (Münich: Hanser, 2001), 355; Austerliť, 351. All further references, to the German and English editions, will be in the main body of the text.

${ }^{40}$ W. G. Sebald, 'Austerlitz [Manuskript]', Bestand A: Sebald, HS002277561, Mappe 1-3., Deutsches Literaturarchiv Marbach. For example, the mother is Amalia on 351, Alma on 256; the friend is Stela on 219 and 302.

${ }^{41}$ Ibid.. Mappe 3, pp. 356-7.

${ }^{42}$ Dan Jacobson, Heshel's Kingdom (London: Hamish Hamilton, 1998), 207; xi. 